\title{
KARAKTERISTIK HUKUM ISLAM \\ (KONSEP DAN IMPLEMENTASINYA)
}

Oleh: Sya'ban Mauluddin

\begin{abstract}
Abstrak
Hukum Islam adalah hukum yang berwatak, ia mempunyai karakteristik yang berbeda dengan ilmu hukum lainnya, Karakter tersebut merupakan ketentuan-ketentuan yang tidak berubah-ubah, yaitu dimana hukum Islam bersifat takamul (sempurna), wasatiyah (seimbang, harmonis), harakah (bergerak dan berkembang sesuai dengan perkembangan zaman). AI-Qur'an memperkenalkan satu konsepsi hukum yang bersifat integra1, Di dalamnya terpadu antara Sunatullah dengan Sunnah. Sebagaimana terpadu antara aqidah dan moral, terpadunya dengan hukum dalam rumusan yang diajarkan al-Qur'an. Dengan sifatnya yang demikian, maka hukum Islam memiliki kekuatan sendiri yang tidak tergantung pada adanya sesuatu kekuasaan sebagai kekuatan pemaksa dari luar hukum tersebut.
\end{abstract}

\section{PENDAH UL UAN}

Definisi hukum menurut hukum positif adalah peraturanperaturan yang bersifat memaksa, yang menentukan tingkah laku manusia dalam lingkungan masyarakat yang dibuat oleh badan-badan resmi yang berwajib. Pelanggaran terhadap aturan-aturan tersebut berakibat diambilnya tindakan berupa sanksi dengan hukuman tertentu. ${ }^{1}$

Sedangkan hukum dalam ruang lingkup pembahasan hukum Islam dapat dibagi dalam kategori syari'at Islam dan fikih Islam. Syari'at Islam diterjemahkan dengan Islamic Law, sedang fikih Islam diterj emahkan dengan Islamic Jurisprudence. Di dalam bahasa Indonesia untuk syari'at Islam sering dipergunakan istilah hukum syari'at atau hukum syara' untuk fikih Islam dipergunakan istilah hukum fikih atau kadang-

${ }^{1}$ Lihat, C.S.T Kansil, Pengantar Ilmu Hukum, Jilid 1, (Cet. IX, Jakarta: Balai Pustaka, 1992), h. 12. 
kadang hukum Islam. Syari'at adalah landasan fikih, fikih adalah pemahaman tentang syari'at. $^{2}$

Dengan demikian Islam dan hukumnya yang bersifat abadi dan kekal mempunyai dua bentuk ajaran, yakni ajaran dasar dan ajaran non dasar. Ajaran dasar adalah ajaran yang bersifat tetap, absolut, tidak berubah, mutlak dan bersifat dogmatis Ajaran ini biasanya disebut ajaran yang pasti Qath'i. Sedangkan ajaran non dasar ada adalah ajaran yang nisbi, relatif, tidak tetap, boleh berubah, dan tidak mengikat Ajaran ini biasanya disebut kelompok ajaran yang Zhanni.

Pada saat ini, dimana Islam diri umatnya dihadapkan pada satu tahap kultural yang dinamakan Pasca Modernisme, yaitu suatu fase yang melampaui masa modern atau identik dengan masyarakat informasi. Dima- na terjadi perailhan dari sikap-sikap yang serba tradisional kepada sikap-sikap yang rasional dan prag-coatis Perubahan yang menghendaki jawaban dan penentuan hukum dari sudut kacamata Islam. Lebih-lebih masih terdapat masyarakat yang beranggapan bahwa agama Islam hanya bersifat dogmatis statis dan menentang pembahartian.

Ini berarti bahwa diperlukan pemahaman integral terhadap karakter dan watak dari hukum Islam serta problema-problema yang dihadapi masyarakat saat ini, untuk mendapatkan gambaran yang sesuai dengan judul makalah ini, maka yang menjadi permasalahan adalah:

1. Apakah tujuan pengundangan hukum Islam?

2. Bagaimanakah sifat dari karakeristik hukum Islam?

3. Bagaimanakah implementasi hukum Islam dalam kehidupan?

\section{TUJUAN PENGUNDANGAN HUKUM ISLAM}

Secara umum sering dirumuskan bahwa tujuan hukum Islam adalah untuk kebahagiaan hidup manusia di dunia ini dari di akhirat kelak, dengan jalan meng-mbil segala yang bermanfaat dan mencegah atau menolak yang mudarat yaitu yang tidak berguna bagi hidup manusia, baik rohani matipun jasrnani, individual dan sosial.

${ }^{2}$ Lihat, Mohammad Daud Ali, Hukum Islam, Pengantar Ilmu Hukum dan Tata Hukum Islam di Indonesia, (Cet. III; Jakarta: PT. Raja Grafindo Persada, 1993), h. 44. 
Jika diteliti semua fan dari penjelasan-penjelasan Ushul Figh yang merupakan asas 11 ukumnya, semua ajaran hukumnya mengarah pada tiga aspek dasar, yaitu Pertama mendidik perorangan dan pribadi supaya menjadi sumber kebaikan buat masyarakat dan jama'ah, dan jnganlah pribadi (perorangan) Itu menjadi sumber malapetaka buat masyarakat. ${ }^{3}$

Hal ini dapat dilihat pada ajaran-ajaran akhlak dan ibadat, terutama ibadat yang empat. Shalat dengan selurh haiah, kaifiyat dan cara-caranya serta berkumpul manusia untuk mclaksanakannya adalah merupakan pusat pendidikan pribadi dan jama demikian halnya puasa dan haji dimana dalam jiwa ibadat ini mengandung unsur-unsur ikatan Kemasyarakatan atas dasar tali kasih yang lebih jelas. Lebih Lebih lagi zakat terdapat di dalamnya unsureunsur ikatan masyarakat yang lebih dalam lagi.

Kedua: Syariat ini bertujuan untuk menegakkan keadilan, baik keadilan dalam jama'ah Islamiyah

alas dasar jalinan aqidah dan sosial maupun kcadilan dengan non muslim atas dasar hubungan sosial. $^{4}$

Sebagaimana tercantum dalam finnan Allah SWT. Q.S. Al-Maidah (5): 8 sebagai berikut: "...Dan jangwilah sekali-kali kebencianmu terhadap sesuatu kaum mendorong kamu untuk berlaku tidak adil, berlaku adillah, karena adil itu lebih dekat kepada takwa... ${ }^{5}$

Kemudian dalam syari'at Islam adalah sasaran utama dalam setiap segi dan aspek ajaran syariatnya baik yang berhubungan dengan hukum-hukum mu'amalat qadla' dan scbagainya. Dan arah utama dari keadilan Ini adalah dengan menempatkan semua manusia sama dihadapkan hukum dengm tidak membedakan kaya dan miskin, lemah dan kuat serta tingkatan-tingkatan yang dicenninkan manusia satu sama lainnya.

Ketiga : Yang merupakan tujuan akhir dari pengundangan hukum dalam syara' adalah terwujudnya kemaslahatan manusia. ${ }^{6}$

${ }^{3}$ Lihat Dahlan Idhamy, karakteristik Hukum Islam, (Cet. I; Surabaya: Al-Ikhlas, 1994), h. 18.

${ }^{4}$ Ibid. h, 159 .

${ }^{5}$ Departemen Agama RI. .Al-Qur'an dan Terjetnahannya, (Surabaya: Mahkota, 1989). 
Setiap perkara hukum yang disyari'atkan dalam al-Qur'an dan Hadis, semua di dalamnya terdapat kemaslahatan hakiki yang umum clan bukan khusus untuk Suatu kelompok dam lingkungan tertentu, dan kemaslahatan ini bukanlah ukurannya pada penalaran pikiran manusia yang sifatnya nisbi dari relatif.

Asas-asas kemaslahatan manusia tersebut, dituangkan dalam pembentukkan hukum dengan merealisir kemaslahatan manusia dengan menjamin kebutuhan pokoknya dan memenuhi kebutuhan sekunder serta kebutuhan pelengkap.

Adapun hal yang bersifat dharuri, yaitu sesuatu yang menjadi pokok kebutuhan kehidupan manusia, dan wajib adanya untuk menegakkan kemaslahatan bagi manusia itu (primer). Apabila tanpa adanya sesuatu itu, maka akan terganggu kehannonisan kehidupan manusia, dan, tidak akan tegak kemaslahatankemaslahatan tersebut, serta terjadilah kehancuran dan kerusakan bagi manusia, hal-hal yang bersifat primer (dharuri) bagi manusia dalam pengertian ini berpangkal kepada memelihara lima perkara: agama, jiwa. akal, kehormatan, dan harta. ${ }^{7}$

Sedangkan hal yang bersifat hajjiy (sekunder), ialah sesuatu yang diperlukan oleh manusia dengan maksud untuk membuat ringan dan lapang, juga untuk kesulitankesulitan beban yang hams dipikul. Dari tahsini yaitu sesuatu yang dituntut oleh nonna dan tatanan hidup serta berperilaku menurut jalan yang lurus. Hal-hal yang bersifat tahsini dalam pengertian ini adalah berpangkal pada akhlak mulia, tradisi yang baik dan segala tujuan perikehidupan manusia menurut jalan yang paling baik. ${ }^{8}$

Dari uraian di atas, dapat dipahami bahwa tujuan pengundangan hukum Islam dapat dilihat dua segi yakni dari segi pembuat hukum Islam itu sendiri yaitu Allah dan Rasul-Nya, dengan tujuan untuk memenuhi keperluan hidup yang bersifat primer, sekunder dan tersier (dharurivah, hajjiyah, dan tahsinivvah). Dan dari segi manusia yang menjadi pelaku dan pelaksana hukum Islam tersebut. Dengan tujuan hukum Islam itu adalah, untuk ditaati dan dilaksanakan oleh manusia dalam kehidupannva sehari-hari dengan

${ }^{6}$ Lihat, Dahlan Idhamy, Op.cit., h. 20.

${ }^{7}$ Lihat Abdul Wahhab Khalaf, K.aidahKaidah Hukuin Islam (Cet. IV, Jakarta: PT. Raja Grafindo Persada, 1994), h. 313.

${ }^{8}$ Ibid. 
cara mengambil segala yang bermanfaat dan mencegah atau menolak yang mudarat bagi kehidupannya.

\section{SIFAT DAN KARAKTERISTIK HUKUI ISLAM}

Hakikat hukum Islam itu tiada lain adalah syari'ah itu sendiri, yang bersumber dari al-Qur'an, Sunnah Rasul dari al-Ra'yu Doktrin pokok dalam Islam itu sendiri yaitu konsep tauhid merupakan fondasi dalam struktur hukum Islam, yaitu hubungan hablun win Allah (hubungan vertikal), dari hablun Min al-nas (hubungan horizontal), al-anirit bil nia'ruf wa alnahyu al-munkar, taqwa, adil, dan bijaksana serta mendahulukan kewajiban daripada hak dan kewenangan.

Sehubungan dengan doktrin di atas, maka terdapat lima sifat dan karakteristik hukum Islam yaitu:

\section{Sempurna.}

Syari'at Islam diturunkan dalam bentuk yang umum dari garis besar permasalahan. Oleh karena itu hukum-hukumnya bersifat tetap, tidak berubah-ubah lantaran berubahnya masa dari berlainannya tempat. Untuk hukum-hukum yang lebih rinci, syari'at isi am hanya menetapkan kaedah dan memberikan patokan umum. penjelasan dan rinciannya diserahkan pada ijtihad pemuka masyarakat. ${ }^{9}$

Menurut M. Hasbi AshShiddieciy, salah satu ciri hukum Islam adalah takamul yaitu, lengkap, sempurna dan bulat, berkumpul padanya aneka pandangan hidup. Menurutnya hukum Islam menghimpun segala sudut dan segi yang berbeda-beda di dalam suatu kesatuan karenanya hukum Islam tidak menghendaki adanya pertentangan antara Ushul dengan Furu', tetapi satu sama lain saling lengkap-melengkapi kuat-menguatkan. ${ }^{10}$

2. Elastis.

${ }^{9}$ Lihat, H. Fathurrahman Djamil, Filsafat Hukum Islam, bagian pertama (Cet. I: Jakarta: Logos, 1997), h. 46.

${ }^{10}$ Lihat, M. Hasbi Ash-Shiddieu, Falsafah Hukum Islam (Cet. V, Jakarta: Bulan Bintang, 1993), h. 105. 
Hukum Islam juga bersifat elastis (lentur, Luwes), Ia meliputi Segala bidang dan lapangan kehidupan manusia,. Hukum Islam memperhatikan berbagai segi kehidupan baik bidang muamalah, ibadah, jinayah dan lain-lain. Meski demiklan ia tidak memiliki dogma yang kaku, keras dan memaksa. Hukum Islam hanya memberikan kaidahkaidah urn urn yang mesti dijalankan oleh umat manusia. ${ }^{11}$

Sebagai bukti bahwa hukum Islam bersifat elastis. Dapat dilihat dalam salah satu contoh dalam kasus jual beli; bahwa ayat hukum yang berhubungan dengan jual bell (Q.S. al-Bagarah (2): 275, 282, Q.S. an-Nisa' (4): 29, dan Q.S. (62): 9). Dalam ayat-ayat tersebut diterangkan hukum bolehnya jual beli, persyaratan keridhaan antara kedua belah pihak, larangan riba, dan larangan jual beli waktu azan Jum'at. Kemudian Rasul menjelaskan beberapa aspek jual beli yang lazim berlaku pada masa beliau. Selebihnya, tradisi atau adat masyarakat tertentu dapat, dijadikan sebagai bahan penetapan hukum jual beli.

3. Universal dan Dinamis.

Ajaran Islam bersifat universal. Ia meliputi seluruh alam tanpa tapal batas, tidak dibatasi pada daerah tertentu seperti ruang lingkup ajaranajaran Nabi sebelumnya. Berlaku bagi orang Arab dan orang `Ajam (non Arab). Universalitas hukum Islam ini sesuai dengan pemilik hukum itu sendiri yang kekuasaan tidak terbatas. Di samping itu, hukum Islam mempunyai sifat yang dinamis (cocok untuk setiap zaman). ${ }^{12}$

Hukum Islam memberikan kepada kemanusiaan sejumlah hukum yang positif yang dapat dipergunakan untuk segenap masa dan tempat. Dalam gerakannya hukum Islam menvertai perkembangan manusia, mempunyai kaidah asasiyah, yaitu ijtihad. Ijtihadlah yang akan menjawab segala tantangan masa, dapat memenuhi harapan zaman dengan tetap memelihara kepribadian dari nilai-nilai asasinya. ${ }^{13}$

Dalam kaitannya dengan keuniversalan tersebut dapat dipahami lewat konstitusi negara mushm pertama. Madinah, menyetujui dan melindungi

${ }^{11}$ Lihat, H. Faturrahman Djamil, op.cit. h. 47.

${ }^{12} \mathrm{Ibid}$, h. 49.

${ }^{13}$ Lihat, M. Hasbi As-Shiddiegy, Op-cit.; h. 108 
kepercayaan non-muslim dan kebebasan mereka untuk mendakwahkan. Konstitusi ini merupakan kesepakatan antara Muslim dan Yahudi, serta orang-orang Arab yang bergabung di dalamnya. Non-Muslim dibebaskan dari keharusan membela negara dengan membayar Jizyah, yang. berarti hak hidup dan hak milik mereka dijamin. Istilah Zimmi, berarti orang non-Muslim yang dilindungi Allah dan Rasul. Kepada orang-orang non-Muslim itu diberikan hak Otonomi yudisial tertentu. Warga Negara dan kalangan ahli kitab dipersilahkan menyelenggarakan keadilan sesuai dengan apa_yang Allah wahyukan.

4. Sistematis.

Arti dari pc.myataan bahwa hukum Islam itu bersifat sistematis adalah bahwa hukum Islam nu mencerminkan sejumlah doktrin yang bertalian secara logis, sating berhubungan satu dengan lainnya. ${ }^{14}$

Perintah shalat dalam al-Qur'an senantiasa diiringi dengan perintah zakat. Dan berulang-ulang Allah berfirman "makan dan minumlah kamu tetapi jangan benlebihan". Dalam hal ini dipahami bahwa hukum Islam melarang seseorang hanya mermuamalah dengan Allah dan melupakan dunia. Manusia diperintahkan mencari rezeki, tetapi hukum Islam melarang sifat imperial dan kolonial kctika mencari rezeki tersebut.

\section{Hukum Islam bersifat Ta'aquli dan Ta'abbudi.}

Sebagaimana dipahami bahwa syari'at Islam mencakup bidang mu'amalah dan bidang ibadah. Dalam bidang ibadah terkandung nilai-nilai ta'abbudil ghairu ma' qulah al ma'na (Irasional), artinya manusia tidak boleh beribadah kecuali dengan apa yang telah disyari'atkan dalam bidang ini, tidak ada pintu ijtihad bagi umat manusia. Sedangkan bidang muamalah, di dalamnya terkadang nilai-nilai ta'aquli/ma'aqulah al-ma'na (rasional). Artinya, umat Islam dituntut untuk berijtihad guna membumikan ketentuan-ketentuan syari'at tersebut. ${ }^{15}$

\footnotetext{
${ }^{14}$ Lihat, H. Fathurrahman Djamil, Op.cit., h. 51

${ }^{15}$ Ibid, h. 52.
} 
Dengan demikian hukum Islam yang bersifat irasional, aturanaturan hukum Islam itu sah atau baik, karena semata-mata eksistensi kebajikan yang terkandung di dalamnya, bukan karena rasionalitasnya.

Dari uraian di atas bahwa sifat hukum Islam tersebut, mempunyai hubungan simbiosis (sangat erat), sehingga dapat dipahami bahwa kelima sifat yang telah disebutkan itu, merupakan satu keterpaduan karakteristik hukum Islam yang sangat sesuai dengan fitrah manusia sebagai makhluk Allah SWT, yang dilengkapi dengan dua kelebihan daripada makhluk lainnya yaitu akal (intelegensia) dari kalbu (hati nurani).

Selanjutnya ciri-ciri kekhusushukum Islam yang membedakannya dengan hukum lain, adalah:

1. Hukum Islam berdasar atas wahyu Allah AWT, yang terdapat dalam al-Qur'an dan dijelaskan oleh Sunnah Rasul-Nya.

2. Hukum Islam dibangun berdasarkan prinsip akidah (iman dan tauhid) dan akhlak (moral).

3. Hukum Islam bersifat universal (alami), dan diciptakan untuk kepentingan seluruh umat manusia (rahmatan lil 'alamin).

4. Hukum Islam memberikan sanksi di dunia dan sanksi di akhirat (kelak).

5. Hukum Islam mengarah kepada jama'iyah (kebersamaan) yang seimbang antara kepentingan individu dan masyarakat.

6. Hukum Islam dinamis dalam menghadapi perkembangan sesuai dengan tuntutan waktu dan tempat.

7. Hukum Islam bertujuan menciptakan kesejahteraan di dunia dan kesejahteraan di akhirat. ${ }^{16}$

\section{INIPLENIENTASI HUKUM ISLAM DALAM KEIIIDUPAN}

Berdasarkan analisis doktrin dan sifat hukum Islam, dapat dipaliami bahwa tidak ada satupun unsur-unsur hukum Islam yang mengandung nilai negatif. Sebaliknya pesan-pesan yang terkandung dalam al-Qur'an dan Hadis itu berintikan satu hal yang sangat positif yang dirumuskan dalam al-Qur'an yaitu rahmatan lil 'alamin, yaitu Islam menawarkan

${ }^{16}$ Lihat, H. Suparman Usman, Hukum Islam Asas-Asas dart Pengantar Studi Hukum Islam Dalam Tata Hukum Indonesia, (Cet. I, Jakarta: Gaya Media Pratama, 2001), h. 6465. 
kesejahteraan dan kebahagiaan hidup yang hakiki secara universal kepada seluruh manusia, bukan kebahagiaan yang semu dan temporer.

Hukum Islam adalah hukum Allah yang menciptakan alam semesta ini, termasuk manusia di dalamnya. Hukumnya pun meliputi semua ciptaan-Nya itu. Ada yang jelas sebagaimana yang tersebut dalam al-Qur'an, ada pula yang tersirat yang bersi fat Zhanni dalam al-Qur'an dan Hadis, serta pada hukum Allah yang tersirat dibalik lafaz al-Qur'an dan Hadis, itulah ra'yu atau ijtihad manusia yang memenuhi syarat, berperan tanpa batas mengikuti dan mengerahkan perkembangan masyarakat menentukan hukum dan Mengalami berbagal masalah yang timbul sebagai akibat perkembangan ilmu dan teknologi yang diciptakannya. ${ }^{17}$ Penghormatan dan penghargaan kepada setiap orang dalam syari'ah berakar pada ditegakkan berdasarkan firman Allah dalam al-Qur'an dan petunjuk Nabi SAW. Hak-hak sipil seperti berpendapat, mengeluarkan suara dan slogan-slogan yang menuntut persamaan perlakuan politik yang dikenal sekarang, jauh pada masa awal penyiaran Islam telah tercermin dalam konsep syari'ah yaitu konsep persamaan dan keadilan. Kriteria penghormatan dan kemuliaan seseorang hanyalah taqwa, pengabdian pada Allah SWT. ${ }^{18}$

Dengan sifat dan karakteristik hukum Islam maka hukum dari ajaran al-Qur'an itu mempunyai kekuatan sendiri yang tidak sepenuhnya tergantung pada adanya suatu kekuasaan sebagai kekuatan pemaksa dari luar hukum itu. Ide hukum yang diajarkan al-Qur'an berkembang terus dari masa kemasa melalui jalur ilmu. Seandainya hukum yang diajarkan al-Qur'an itu tergantung pada suatu kokuasaan maka sudah lama jenis hukum, itu terkubur dalam perut sejarah. Karcna itu diketahui betapa upaya dari kekuasaan-kckuasaan yang mampu menaklukkan wilayah-wilayah Islam dan umatnya serta upaya melikuidasi budaya dan hukumnya. Tapi ternyata hukum Islam dari ajaran al-Qur'an itu dapat memperlihatkan daya tahannya yang ampuh.

Ia tetap bertahan bahkan berkembang dalam bentuk baru melalui proses taqnin (dirumuskan menjadi hukum positif melalui yurisprudensi), bahkan dibentuk melalui perundang-undangan. Di Indonesia misalnya bentuk perundang-undangan tersebut adalah

${ }^{17}$ Lihat, H. Mohammad Daud Ali, Op-cit., h. 111.

${ }^{18}$ Lihat, Abdurrahman I. Doi, Syarrah Kodfikasi Hukum Islam. (Cet I, Jakarta: IT, Rineka Cipta, 1993), h. 13. 
UU, No 1/1974 tentang Perkawinan, UU. No. 7/1989 tentang Peradilan Agama, Inpres RI, No. 1/1991 tentang Kompilasi Hukum Islam, dan sebagainya.

Implementasi hukum Islam dalam kehidupan akan berjalan terus, sekalipun mengalami pasang surut dalam penerapannya, karena memang demikianlah hukum sejarah dalam sunatullah sendiri. Dan bidang yang menyangkut sosial kemasyarakatan lebih banyak mendominasi perkembangan itu. Perkembangan bidang fikihnya yang merumuskan hukum sosial kemasyarakatan itu, sangat berjasa dalam menumbuhkan kesadaran hukum dan sikap normatif dalam kehidupan umat Islam.

\section{PENUTUP}

Dari uraian yang telah dikcmukakan maka dapatlah disimpulkan sebagai berikut:

1. Bahwa melihat pada tujuan diundangkannya hukum Islam yaitu mewujudkan kemaslahatan manusia dan meienyapkan mafsadat. Maka segala maslahat yang diatur dalam nash adalah menjadi hujjah atau sumber hukum Islam. Dan maslahat tidak berlaku pada hukum-hukum ibadat yang sifatnya ta'abbudi, hanya berlaku dalam bidang yang sifatnya ta'aqquli (rasional).

2. Hukum Islam adalah hukum yang berwatak, ia mempunyai karakteristik yang berbeda dengaii ilmu hukum lainnya, Karakter tersebut merupakan ketentuan-ketentuan yang tidak berubah-ubah, yaitu dimana hukum Islam bersifat takamul (sempurna), wasatiyah (seimbang, harmonis), harakah (bergerak dan berkembang sesuai dengan perkembangan zaman).

3. AI-Qur'an memperkenalkan satu konsepsi hukum yang bersifat integra1, Di dalamnya terpadu antara Sunatullah dengan Sunnah. Sebagaimana terpadu antara aqidah dan moral, terpadunya dengan hukum dalam rumusan yang diajarkan alQur'an. Dengan sifatnya yang demikian, maka hukum Islam memiliki kekuatan sendiri yang tidak tergantung pada adanya sesuatu kekuasaan sebagai kekuatan pemaksa dari luar hukum tersebut. 